University Heart Journal

Vol. 4 No. 2 July 2008

\title{
Effects of hyperuricemia on perinatal outcome in hypertensive disorder of pregnancy
}

\author{
Asma Ul Hosna1, A.K.M. Mohiuddin Bhuiyan², Noor-E-Ferdous', Md. Khurshed Ahmed², Md. \\ Abu Siddique2, Mohammad Salman², Sultana Razia Begum¹, Md. Mukhlesur Rahman² \\ and Md. Razib Ahsan. ${ }^{2}$ \\ ${ }^{1}$ Department of Obstetrics \& Gynaecology, Bangabandhu Sheikh Mujib Medical University, Shahbag, Dhaka. \\ ${ }^{2}$ Department of Cardiology, Bangabandhu Sheikh Mujib Medical University, Shahbag, Dhaka. \\ Address for Correspondence \\ Dr. Asma Ul Hosna, Assistant Professor, Department of Obstetrics \& Gynaecology, BSMMU, Dhaka.
}

\begin{abstract}
The purpose of this study was to detect elevated uric acid level in maternal blood, presumably due to decrease renal urate excretion, for early detection of hypertensive disorder in pregnancy.

This study showed that serum uric acid was significantly elevated in all cases of preeclampsia. The present study showed that serum uric acid levels were significantly elevated in eclampsia as compared with the levels in pregnancies complicated by hypertension $(\mathrm{p}<0.05)$. The level of uric acid above $4.5 \mathrm{mg} / \mathrm{dl}$ is indicative of preeclamptic process and in such cases; the subjects deserve careful and close clinical follow up. Increasing higher concentration of uric acid i.e. $5.7 \mathrm{mg} / \mathrm{dl}$, $6.3 \mathrm{mg} / \mathrm{dl}$, and $6.72 \mathrm{mg} / \mathrm{dl}$ was observed in pregnancy with chronic hypertension, preeclampsia and eclampsia respectively. These results showed that serum uric acid could be used as a sensitive indicator of severity of preeclampsia. Out of 100 cases, there were 20 preterm baby and others such as stillbirth and IUD. So, these entire abnormal fetal outcomes were in the hyperuricaemic group and 5.37 times higher as compared to low serum uric acid group. Mean birth weight of preeclampsia and eclampsia were $2.31 \mathrm{~kg}$ and $2.30 \mathrm{~kg}$ respectively compared with $2.5 \mathrm{~kg}$ in chronic hypertension group.
\end{abstract}

\section{Introduction}

Hypertensive disorder of pregnancy are responsible for a significant amount of maternal and perinatal morbidity mortality. Pregnancy may induce hypertension in women who are normotensive before pregnancy and may aggravate hypertension in those that are hypertensive before pregnancy. 1,2

Studies shows that preeclampsia is responsible for $10-15 \%$ of maternal death. But there is no community based statistics regarding preeclampsia and eclampsia in Bangladesh. Health facilities available in our country are deficit than that of our neighbours.3,4 Therefore, both incidence and prevalence of preeclampsia and eclampsia probably higher in our country. In Dhaka Medical College hospital from 1998 to October 2000, maternal mortality rate was 28 per 1000 total birth. Among the causes of maternal death, eclampsia ranks first that is $47.8 \% .^{5}$

Confirm that hypertensive disorder of pregnancy is still the $2^{\text {nd }}$ most common cause of maternal mortality, accounting for $15.5 \%$ direct death. Hypertension in pregnancy is also responsible for $18 \%$ of fetal and infant mortality and $46 \%$ of infants born small for gestational age. ${ }^{6-8}$

Early screening for preeclampsia may allow vigilant antenatal surveillance and appropriate timing of fetal delivery in order to avoid serious sequelae. Unfortunately, various haemodynamic and biochemical measures have been found to have limited accuracy as screening measures for this condition.

Elevated uric acid level in maternal blood, presumbly due to decreased renal urate excretion, are frequently found in women with preeclampsia. Various studies conducted to find out the relationship between elevated serum uric acid level and preeclampsia. ${ }^{9}$

Studies of serum uric acid level in normal and hypertensive pregnancy and its relation with the early diagnosis of preeclampsia, severity of preeclampsia and associated perinatal outcome have been done in various parts of the world by many workers. ${ }^{10-16}$ As there are evidences from studies in other countries, in this study it would be explore wheather raised serum uric acid has an adverse effect on perinatal outcome in preeclamsia and eclampsia

\section{Aims and objectives}

To determine the relationship between hyperuricaemia and fetal outcome in hypertensive disorder of pregnancy.

\section{Material and methods}

The prospective study was carried out in the Department of Gynecology and Obstetrics, DMCH and BSMMU during the period of July 2007 to June 2008. One hundred preg- 
nant women with hypertensive disorders such as preeclampsia, eclampsia and chronic hypertension were taken as case. Hundred women with normal pregnancy were taken as control. Blood for serum uric acid were taken and determined by enzymatic colorimetric method.

\section{Results}

This was a cross sectional case control study. Mean age of the subjects was $25.15 \pm 5.0$ years in case group and $23.14 \pm 4.6$ years in control group.

Table I: Family history of hypertension

\begin{tabular}{lccc}
\hline $\begin{array}{c}\text { Family history of } \\
\text { hypertension }\end{array}$ & \multicolumn{2}{c}{ Study subjects } & p value \\
& $\begin{array}{c}\text { Case } \\
(\mathbf{n}=\mathbf{1 0 0})\end{array}$ & $\begin{array}{c}\text { Control } \\
(\mathbf{n}=\mathbf{1 0 0 )}\end{array}$ & \\
\hline Yes & $48(48.0 \%)$ & $20(20.0 \%)$ & 0.001 \\
No & $52(52.0 \%)$ & $80(80.0 \%)$ & \\
\hline
\end{tabular}

$\mathrm{p}$ value $\leq 0.05$ is significant.

Table II: Fetal outcome in different hypertension group subjects.

\begin{tabular}{|c|c|c|c|c|}
\hline \multirow[b]{2}{*}{$\begin{array}{c}\text { Fetal } \\
\text { outcome }\end{array}$} & \multicolumn{4}{|c|}{ Study subjects } \\
\hline & $\begin{array}{c}\text { Eclampsia } \\
(\mathrm{n}=\mathbf{3 6})\end{array}$ & $\begin{array}{l}\text { Pre-eclampsia } \\
\qquad(n=46)\end{array}$ & $\begin{array}{c}\text { Gestational. } \\
\text { HTN } \\
(\mathrm{n}=18)\end{array}$ & $\begin{array}{l}\text { Normal } \\
(n=100)\end{array}$ \\
\hline Bad & $27(75.0 \%)$ & $25(54.3 \%)$ & $5(27.8 \%)$ & $2(2.0 \%)$ \\
\hline Good & $9(25.0 \%)$ & $21(45.7 \%)$ & $13(72.2 \%)$ & $98(98.0 \%)$ \\
\hline
\end{tabular}

$\mathrm{p}$ value $\leq 0.05$ is significant

Table III: Comparison of good and bad fetal outcome according to serum uric acid.

\begin{tabular}{lccc}
\hline $\begin{array}{l}\text { Serum Uric } \\
\text { acid (mg/dl) }\end{array}$ & \multicolumn{2}{c}{ Fetal outcome } & P value \\
& Bad (n=59) & Good $(\mathbf{n = 1 4 1 )}$ & \\
\hline$<5.0$ & $14(23.7 \%)$ & $89(63.1 \%)$ & 0.001 \\
$5-6.9$ & $19(32.2 \%)$ & $39(27.7 \%)$ & \\
$>7$ & $26(44.1 \%)$ & $13(9.2 \%)$ & \\
\hline
\end{tabular}

$\mathrm{p}$ value $\leq 0.05$ is significant

Table IV: Outcome of pregnancy and serum uric acid level.

\begin{tabular}{cccc}
\hline Pregnancy outcome & \multicolumn{2}{c}{ S. Uric acid (mg/dl) } & P value \\
\hline Live birth & N & Mean \pm SD & \\
\cline { 2 - 3 } Preterm & 141 & $4.6 \pm 1.5$ & \\
Others & 20 & $6.5 \pm 2.1$ & 0.001 \\
Total & 39 & $6.8 \pm 2.0$ & \\
\hline
\end{tabular}

$\mathrm{p}$ value $\leq 0.05$ is significant

\section{Discussion}

Preeclampsia has been traditionally defined as a triad of hypertension, edema and proteinuria. It is now recognized that edema is so consistent a part of normal pregnancy that it has little or no value as a diagnostic sign of preeclampsia. Preeclampsia is a late and inconstant feature of the disorder. So, the only useful early sign is a change in the blood pressure. Because blood pressure measurement contains many errors, this only early diagnostic sign of preeclampsia is unsatisfactory. A rising serum uric acid is now recognized as an early feature of preeclampsia and its measurement greatly increases the accuracy of diagnosis. ${ }^{11-13}$

This study showed that serum uric acid was significantly elevated in all cases of preeclampsia. Table shows the figures quoted by some of the investigators and compares them with this study. Increased serum uric acid level is an early and characteristic feature of preeclampsia, which helps to differentiate this disorder from essential and other chronic forms of pre-existing hypertension complicating pregnancy. ${ }^{10-16}$

In a carefully controlled and extensive investigation, Lim and Frideman measured serum uric acid concentration in healthy pregnant females, patients with preeclampsia and patients with hypertensive vascular disease. They determined the mean serum uric acid level in the last trimester of pregnancy for the normal women to be $3.5 \pm 0.6 \mathrm{mg} \%$. Patients with hypertension had similar concentration of serum uric acid, $3.7 \pm 1.1 \mathrm{mg} / \%$, whereas the mean level for patient with histologically proven preeclampsia was $6.4 \pm 1.7 \mathrm{mg} / \%$. Thus a significant increase in mean serum uric acid concentration was present in patients with preeclampsia compared to those with hypertensive vascular disease and normal pregnant women. ${ }^{20,21}$ Based on careful clinical criteria in addition to histological examination of the kidney in preeclampsia, these authors brought strong evidence to support the presence of hyperuricaemia in toxemia of pregnancy. Furthermore, they reported patients with microscopically determined glomerular alterations whose blood urea nitrogen and non-protein nitrogen concentration were not elevated and yet demonstrated increased uric acid concentration. Thus these authors showed the usefulness of serum uric acid measurements as an early and sensitive indicator of the presence of the preeclamptic state. Comparison of the serum uric acid determination in normal pregnancy, mild preeclampsia and severe preeclampsia was done, in some of the previously published reports and in the current study.

Lim et.al. studied 17 pre-eclamptic, 22 hypertension and 13 normal pregnant women in the $3^{\text {rd }}$ trimester. The study found that serum uric acid levels were significantly elevat- 
ed in pre-eclamptic patients. The mean serum uric acid level for pre-eclamptic patients was $6.6 \mathrm{mg} / \mathrm{dl}$ as compared with $5.4 \mathrm{mg} / \mathrm{dl}$ for hypertensive patients and $4.2 \mathrm{mg} / \mathrm{dl}$ for the normal pregnant women.

The present study showed that serum uric acid levels were significantly elevated in eclampsia as compared with the levels in pregnancies complicated by hypertension $(\mathrm{p}<0.05)$. The level of uric acid above $4.5 \mathrm{mg} / \mathrm{dl}$ is indicative of preeclamptic process and in such cases; the subjects deserve careful and close clinical follow up. Increasing higher concentration of uric acid i.e. $5.7 \mathrm{mg} / \mathrm{dl}, 6.3 \mathrm{mg} / \mathrm{dl}$, and $6.7 \mathrm{mg} / \mathrm{dl}$ was observed in pregnancy with chronic hypertension, preeclampsia and eclampsia respectively. These results showed that serum uric acid could be used as a sensitive indicator of severity of preeclampsia.

Mustaphi and Gopalan found that an elevation of the mean values for uric acid correlated with the degree of severity of the toxemia. Lim and Frideman in 1998 found that the concentration of serum uric acid also correlated well with severity of the glomerular lesion. Anna and Leo concluded that the level of serum uric acid appears to be a sensitive index of the severity of preeclampsia. ${ }^{17,20,21}$

This study of 100 patients with hypertensive disorder of pregnancy shows that serum uric acid level is an useful index of fetal status and this results are comparable to those of Lim \& Frideman, Anna \& Leo Kee-Hak Lim, Williams $\&$ Galernea. The increase in mean serum uric acid was more evident in women with eclampsia and preeclampsia, i.e. $6.8 \mathrm{mg} / \mathrm{dl}$ and $6.3 \mathrm{mg} / \mathrm{dl}$ respectively- when compared with values in chronic essential hypertension with pregnancy $(5.7 \mathrm{mg} / \mathrm{dl}) .^{22-28}$

Out of 100 cases, there were 20 preterm baby and others such as stillbirth and IUD. So, these entire abnormal fetal outcomes were in the hyperuricaemic group and 5.3 times higher as compared to low serum uric acid group. ${ }^{29}$

The mean duration of gestation at delivery was also significantly lowered in preeclampsia and eclampsia. These findings were consisted with Varma and Williams et al. who found that perinatal morality was markedly increased when maternal serum uric acid concentration were raised, generally in association with preeclampsia and eclampsia. Maternal hypertension, even severe, without hyperuricaemia was associated with good prognosis for the fetus. ${ }^{35}$, 38,43

The mean birth weight of infants was also reduced in the preeclampsia and eclampsia group compared with patient with chronic hypertensive group. Mean birth weight of preeclampsia and eclampsia were $2.31 \mathrm{~kg}$ and $2.30 \mathrm{~kg}$ respectively compared with $2.5 \mathrm{~kg}$ in chronic hypertension group.
Patients with severe hypertensive group, when associated with rising serum uric acid levels, had a higher incidence of fetal distress, low birth weight infants, a higher perinatal mortality rate and higher incidence of premature intervention of pregnancy. 35,36

The estimation of serum uric acid levels does help to identify those fetuses at risk of developing IUGR and also helps to identify the severity of the hypertensive disease, which is not always obvious as assessed on the basis of blood pressure levels measurements. Patient with chronic hypertension had a better fetal outcome compared to those who had preeclampsia with high uric acid level. However the outcome for the fetus was significantly unsatisfactory when chronic hypertension was associated with high or rising serum uric acid levels. ${ }^{30,31}$

This study indicated that in pregnant women with hypertension, measurement of serum uric acid is a better indicator of the fetal consequences of preeclampsia than the measurement of blood pressure itself. In established preeclampsia the diagnosis is usually clinically evident and the elevation of serum uric acid will simply confirm the diagnosis. ${ }^{32-34}$ But since urate retention is an early feature of the disorder, serum uric acid measurement is of the greatest value where the diagnosis of preeclampsia is in doubt or hypertension of unknown aetiology is present. According to Williams et.al. the time of onset of preeclampsia is of great importance in determining the final outcome of the fetus because the only treatment for the disorder in quick delivery. Since preeclampsia is usually relentlessly progressive disorder, if it starts between 24 and 30 weeks of gestation it may readily progress either to intrauterine death or to a dangerous illness demanding delivery at a time when neonatal survival is unlikely. It is in this difficult situation of early onset of preeclampsia that raised serum uric acid levels correlate most closely with fetal outcome. It is, therefore, possible to the serial measurements of blood pressure and serum uric acid to diagnose the onset of preeclampsia. ${ }^{37-40}$ The time at which the serum uric acid concentration begins to rise is an approximate indicator of the time of onset of the preeclampsia. ${ }^{41-43}$

The value of measuring serum uric acid in hypertensive pregnancy is greatest between 24 and 32 weeks of gestation. Low values indicate a good prognosis for the fetus. ${ }^{44}$ Rising or high values at this time indicate high-risk cases which are better managed and treated in hospital. Early bed rest, monitoring of fetal well being in utero and anticipation of maternal problems related to preeclampsia then ensure the best chances for bringing the pregnancy to stage where planned delivery prevents serious maternal complications and gives the best possible chance of fetal survival. The measurement of serum uric acid is thus of great diag- 
nostic and prognostic value for fetus. This study shows that serial estimation of serum uric acid levels in pregnancies complicated by both preexisting hypertension and preeclampsia help to assess the severity of the illness, and to identify those fetuses that are likely to have IUGR and a high perinatal morbidity and mortality. Because laboratory investigation of serum uric acid is simple, it can be easily performed in any laboratory.

\section{References}

1. Agustin, CA \& Belizam, JM, 'Risk factors for preeclampsia in a large cohort of Latin American and Caribbean Women,' British J Obstet Gynecol, 2000, Vol. 107(1), 75-83.

2. Amanda, M, Cotter, Anne, M, Molloy, Scott, JM, Daly, SF, 'Significance of hyperuricemia in preeclampsia, 'Am J Obstet Gynecol, 2003, vol. 189, 391-96.

3. Amanda, MC, Martin, CM, John JO, Daly, SF, 'Increased fetal DNA in the maternal circulation in early pregnancy is associated with an increased risk of preeclampsia,' Am J Obstet Gynecol, 2004, vol. 191, 515-20.

4. Azim, AKMA, Tahera, D, 'A study on maternal mortality in maternity unit-I, of Dhaka Medical College Hospital from 1986-1989,' Bangladesh J Obstet Gynecol, 1992, vol. 7(2), 56-63.

5. Begum, R, Akter, S, Begum A, Khatun M, Ehsan Q, Begum $\mathrm{S}$, et al. 'Conservative management of eclampsia and severe preeclampsia- A Bangladesh experience' Meds cape General Medicine, 2002, vol. 4(1), 1-2.

6. Calvert, SM, Tuffnell, DJ, Haley, J, 'Poor predictive value of platelet count, mean platelet volume and serum urate in hypertension in pregnancy,' Eur J Obstet Gynecol Reprod Biol, 1996, vol. 64(2),179-84.

7. Claven, T, Djurovic, S, Henriksen, T, 'Dyslipidemia in early $2^{\text {nd }}$ trimester is mainly a feature of women with early onset preeclampsia,' Br J Obstete Gynecol, 2001, vol. 108, 108187.

8. Damien, S, Patric, G, Francies, P, Pierre, L, Serge, B, Gerard, $\mathrm{B}$, et al. 'Aspirin (100mg) used for prevention of preeclampsia in nulliparous women; the Essai Regional Aspirin Mere - Enfant study (Part-1),' British J Obstet Gynecol, 2003, Vol. 110, 475-84.

9. Danna R, Baviera G, Scilipoti, A, Loonardi, I, Leo, R, 'The clinical utility of serum uric acid measurements in preeclampsia and transient hypertension in pregnancy,' Panminerva Med, 2000, vol. 42(2), 101-03.

10. David, MS, Sehdev, HM, Morgan, MA, Propert, K, George, A, Macrones, MSCE, 'Can antenatal clinical and biochemical markers predict the development of severe preeclampsia?' Am J Obstet Gynecol, 2000, vol. 182, 589-94.

11. Dekker, G, Sibai, B, 'Primary, secondary and tertiary prevention of preeclampsia,' The Lancet, 2001, vol. 357, 209-15.

12. Dekker, GA, \& Baha, 'Low dose aspirin in the prevention of preeclampsia and fetal growth retardation,' Am J Obstet Gynecol, 1993, vol. 168, 214-27.
13. Dekker, GA, Sibai, BM, 'Early detection of preeclampsia,' Am J obstet Gynecol, 1991, Vol. 165, 160-72.

14. Emma, N, Helena, S, Cnattingius, S, Lichtenstein, P, 'The importance of genetic and environmental effects for preeclampsia and gestational hypertension,' Britist J Obstet Gynecol, 2004, vol. 111, 200-06.

15. Eugenia, M, Chavarria, Gonzales, L, Gleason, AG, Sojo, I. Reyes, A., 'Serum uric acid levels in normal pregnancy with observation on the renal exertion of water in pregnancy,' Am J Obstet Gynecol, 2002, vol. 187, 595-601.

16. Fircher, RL, Bianculli, KW, Hediger, ML, Scholl, TO, 'Maternal serum uric acid levels in twin gestation,' Obstet Gynecol of New Jersey, 1995, vol. 85(1), 60-64.

17. Gopalan, C, 'Effect of nutrition on pregnancy and lactation,' Bull Wld Hlth Org, 1962, Vol. 26, 203-11.

18. Hall, DR, Odendaal, HJ, Steyn, DW, Grove, D 'Expectant management of early onset severe preeclampsia: Maternal outcome,' Br J Obstete Gynecol, 2000, vol. 107, 1252-57.

19. Junzhang, Troendle, J, Meikle, S, Klebanoff, MA, Rayburn, WF, 'Serum uric acid in preeclampsia and eclampia,' Br J Obstete Gynecol, 2004, vol. 111, 220-25.

20. Kafulafula, GE, Moodley, J, Ojwang, PJ, Kagoro, H, 'Uric acid and endogenous creatinine clearance studies in normal pregnancy and toxemia of pregnancy,' Br J Obstete Gynecol, 2002, vol. 109, 1256-61.

21. Kee-Hak Lim, 'Uric acid levels to diagnose preeclampsia in gestational hypertension,' Am J Obstet Gynecol, 1998, vol. 178, 1067-71.

22. Kieler, H, Zettergren, T, Svenson, H, Dickman, PW, Larsson, A, 'The renal pathology of toxemic of pregnancy,' Br J Obstete Gynecol, 2003, vol, 12-17.

23. Koike, T, Minakami, H, Takayama, T, Ogawa, S, Kuwata, T, Sato, I, 'Elevation of the serum uric acid level preceding the clinical manifestation of preeclampsia in pregnancy, Gynecol Obstet Invest, 1997, vol. 44(2), 97-101.

24. Kuo, VS, RN, RM, Koumantakis, G. and Eileen, DM, Gallery, 'Proteinuria and its assessment in normal and hypertensive pregnancy,' Am J Obstet Gynecol, 1992, vol. 167, 723-28.

15. Lim, KH, Frideman, SA, Ecker, JL, Kao, L, Kilpatrick, SJ, 'The clinical utility of serum uric acid measurments in hypertensive diseases of pregnancy,' Am J Obstet Gynecol, 1998, vol. 178(5), 1067-71.

26. Lim, KH, Steven, A, Frideman, MD, Jeffrey, L, Ecker, MD, $\mathrm{Kao}$, L, et al. 'The clinical utility of serum uric acid measurements in hypertensive disease of pregnancy,' Am J Obstet Gynecol, 1997, Vol. 178, 1067-71.

27. Lucy, C, Chappell, MB, Paul, T, Seed, Briley, A, SRN, Kelly, JF, Beverly, J, Hunt, MD, Charnock-Jones, DS. et al. 'A longitudinal study of biochemical variables in women at risk of preeclampsia,' Am J Obstet Gynecol, 2002, vol. 187, 127-36.

28. Nyame, NA, Sooranna, SR, Jones, J, Alaghbandzodeh, J, Steer, PJ, Hohnson, MR, 'Serum uric acid levels in normal pregnancy with observations on the renal excretion of urate 
in pregnancy,' Br J Obstete Gynecol, 2002, vol. 109, 708-13.

29. Patrick, FW, Arnott, N, Adam, G, Philip, O, Khalid, S, 'How useful is uterine artery Doppler flow velocimetry in the prediction of preeclampsia, intrauterine growth retardation and perinatal death,' British J Obset Gynecol, 2000, vol. 107 (2), 196-208.

30. Philip, JS, Mark, PL., Tina, KJ., Chapple, J, Elliott, P, 'Maternal blood pressure in pregnancy, birth weight and perinatal mortality in first births,' British Med Jr., 2004, vol. 329, 1312-14.

31. Pipkin, FBD. Risk Factors for Preeclampsia, N Engl J Med, 2001, vol. 344(12), 925-26.

32. Rahman, M, Gopalan, S, Dhaliwal, L, Sarker, AK, 'Hyperuricemia and pregnancy induced hypertension- reappraisal,' Indian J Med Sci, 1996, vol. 50(3), 68-71.

33. Redman, CWG, Roberts, JM, 'Management of preeclampsia,' Lancet, 1993, vol. 341, 1451-54.

34. Reynold, C, Mabie, WC, Sibai, BM, Decherny, AH, Nathan, L, 'Hypertensive states of pregnancy,' $9^{\text {th }}$ edition, McGrawHill, New York, 2003, 338-53.

35. Roberts, JM, Cooper, DW, 'Pathogenesis and genetics of preeclampsia,' The Lancet, 2001, vol. 357, 53-56.

36. Roberts, JM, Redman, CWG, 'Preeclampsia: more than pregnancy induced hypertension,' Lancet, 1993, vol. 341, 1447-51.
37. Rodriguez, MH, Damon, I, Masaki, Mestman, J, Kumar, D, Rud R, 'Calcium/creatinine ratio and microalbuminuria in the prediction of preeclampsia,' Am J Obstet Gynecol, 1998, vol. $159,1452-55$.

38. Sibai, BM, 'Preeclampsia of preeclampsia: a big disappointment,' Am J Obstet Gynecol, 1998, vol. 179, 1275-78.

39. Snaith, M, 'Gout hyperuricaemia, and crystal arthritis,' British M Jr, 1995, vol. 310, 521-25.

40. Suzuki, S, Yoneyama, Y, Sawa, R, Otsubo, Y, Takeuchi, T, Araki, K, 'Relation between serum uric acid and plasma adenomic levels in women with preeclampsia,' Gynecol Obstet Invest, 2001, vol. 51(3), 169-72.

41. Tziotis, J, Puchner, AM, Ulaches, G, Creatsas, G, Michalas, $\mathrm{S}$, 'Renal glomerular and tubular function in reaction to hyperuricaemia of preeclampsia and eclampsia,' $\mathrm{Br} \mathrm{J}$ Obstete Gynecol, 2002, vol. 109, 197-201.

42. Walker, JJ, ' Preeclampsia,' Lancet, 2000, vol. 356, 1260-65.

43. Williams, KP, Galerneau, F, 'The role of serum uric acid as a prognostic indicator of the severity of maternal and fetal complication in hypertensive pregnancy,' Can J Obstet Gyncol, 2002, vol. 24(8), 628-32.

44. Yoshikatsu, S, Yamamoto, T, Mabuchi, Y, Tada, T, Szumori, $\mathrm{K}$, et al., 'Simultaneous renal clearances of urea and uric acid in the differential diagnosis of the late toxemia, 'Am J Obstet Gynecol, 2003, vol. 189, 216-21. 